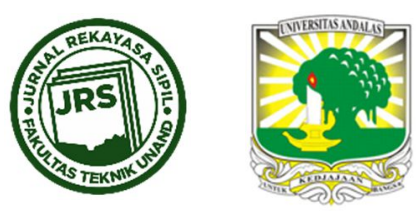

\title{
ANALYSIS OF MAINTENANCE MANAGEMENT AND BUILDING CARE IN THE STATE UNIVERSITY OF PADANG
}

\author{
BUDI AGUS KOMBINO ${ }^{1}$, BENNY HIDAYAT ${ }^{2}$, TAUFIKA OPHIYANDRI ${ }^{3}$ \\ ${ }^{1}$ Department of Civil Engineering, Andalas University (budiaguskombino@gmail.com) \\ ${ }^{2}$ Department of Civil Engineering, Andalas University (Corresponding author $₫$ bennyhidayat@eng.unand.ac.id) \\ ${ }^{3}$ Department of Civil Engineering, Andalas University (ophiyandri@eng.unand.ac.id)
}

Naskah diterima : 20 April 2019. Disetujui: 24 Mei 2019. Diterbitkan : 27 Mei 2019

\section{ABSTRAK}

Since establishment on September 1, 1954, the State University of Padang (UNP) has undergone many changes, especially in the number and shape of existing buildings. It requires a Maintenance and Building Care management system. The purpose of this research is to identify the implementation of PU Ministerial regulation number: 24/PRT/M/2008, about: Guidance of Maintenance and Building Care at UNP. The research method is a descriptive method. Data is collecting by direct observation, distributing questionnaires to 70 respondents divided according to their functions (16 leaders, 12 managers, 30 executors, and 12 students), and collecting maintenance documents and building drawings, literature from research results, journals, building maintenance, and care manuals. The questionnaire is filled in numerical form and processed using an Excel program using descriptive and quantitative analysis that is displayed in the form of bar charts. The results of data processing show that the level of application of Public Works Ministerial regulation at UNP is between $53.01 \%-74.5 \%$, which is categorized as 'good enough' to 'Good'. The results of this calculation cannot be used as a conclusion in the study, the data obtained need to be validated with other data, including data from direct observations in the field, as well as interviews with several leaders at UNP. After validation with the data, it can be concluded thoroughly that the implementation of the Public Works Ministerial regulation at UNP falls into the less good'.

Kata kunci : PU Ministerial regulation number: 24/PRT/M/2008, Maintenance, Care, implementation

\section{BACKGROUND}

The changes have been made by the State University of Padang (Universitas Negeri Padang, hereafter abbreviated in this paper as UNP) that as a form of seriousness to achieve visions as stated in the Vision and Mission of State University of Padang, namely "Being one of the leading universities in the Southeast Asia region in the fields of education, science, technology, sports and art in 2020 based on devotion to God Almighty”. To achieve the vision, a lot of preparations must be made, not only preparing its Human Resources, a good Campus 
Governance System, and financing, but there is something that is not less important to prepare, namely facilities and infrastructure education, one of them is building supporting education and office buildings. Realizing this, UNP began to improve, this was evidenced by the massive development carried out by UNP in recent years, which changed the overall layout and function of buildings in general, including development 11 (eleven) new buildings through IDB loan funds which began the construction process in 2015, as well as 2 buildings with PNBP funds built in 2015 and 2 (two) buildings in 2017, also with PNBP funds. In addition to new buildings as stated above, UNP also has large buildings and facilities to support education and offices that have long been established. With the many activities/activities that exist in a building, the building must also have the strength to support the activities that take place in the building. This condition must also be connected with the city of Padang as a city in the disaster-prone red zone. Buildings built in disasterprone zones certainly have special treatment when compared to buildings that are in disaster safe zones, ranging from planning, development, to maintenance, so that the building can be used as optimally as possible, and does not cause a major disaster for its users. With the development of the number of buildings, the complexity of buildings and their position in earthquake-prone areas, of course, the UNP requires reliable building maintenance and care management system.

The purpose of this study was to overview of the application of the Minister of Public Works Regulation ('PU Regulation') number: 24/PRT/M/2008, about building maintenance and care at UNP.

\section{BUILDING MAITENANCE}

\subsection{General}

Management is a known science about the art of leading an organization which consists of planning, organizing, implementing, and controlling the limited resources to achieve effective and efficient goals and objectives. The purpose of management is to get the best technical method or method so that with limited resources obtained the maximum results concerning accuracy, speed, savings, and safety (Husen, 2009). The activities carried out in management are as follows :

a. Planning. In this activity, anticipation of existing tasks and conditions is anticipated.

b. Organizing. In this activity, identification and classification of types of work are carried out, determining the delegation of authority and responsibility of personnel.

c. Actuating. This activity is the implementation of a predetermined plan.

d. Controlling. In this activity, checking is carried out, whether the programs and rules that have been established can be carried out properly and correctly.

According to the PU Regulation Number: 24/PRT/M/2008, maintenance of the building is an activity to maintain the reliability of buildings and their infrastructure and facilities so that buildings are always functional (preventive maintenance). Preventive maintenance ensure all components of the building facility until the service period, which is divided into two components as follows (Stanford, 2010):

1. Routine maintenance: the function of routine maintenance is to minimize the decline in the quality of building functions.

2. Predictive maintenance: Function to control the significant deterioration of quality of a part of a component. 
Based on the opinion of Iveta Pukitea (2017), building maintenance is defined as "work to keep, restore or improve every part of a building, to maintain the performance of building fabric and its services and surrounds, to an accepted standard and to sustain the utility and value of the building". It includes improvement, refurbishment, upgrading as well as repair works of the existing facilities". The point is that maintenance is how to keep the building under the conditions of the initial standard of development and still be able to support every activity in it.

The building can be similar to a human body that needs to appear optimally. The human body must always be treated and given a balanced nutritional intake so that it can be used optimally. As with the human body, buildings also require preventive action, namely wellplanned maintenance, and this has been recognized for centuries by most people (Corder, 1996); thus the building can be used optimally. Proper building maintenance activities do not interfere with the day-to-day operations of the building; therefore planned maintenance is needed (Mulyandari \& Saputra, 2011). Appropriate maintenance will make the building a right place for building owners or users in activities. Adequate building maintenance activities will also result in long building life following planning, economic value, and the commercial use of buildings and components therein. Without building maintenance activities, the function of a building will experience degradation over time (Supriyatna, 2016).

Building maintenance activities are often ignored by building owners/managers, because looking at planned care is not too significant to do and even tends to add to the routine costs that must be incurred. As a result, many buildings/buildings that only make repairs when finding damaging damages, and generally the level of damage found is already severe, thus requiring higher repair costs than regular and planned maintenance (Rilatupa, 2008). This is confirmed by Suffian's opinion (2013) in his paper said: "Poor and improper building maintenance will definitely cause more damages and costly repair works if left unattended".

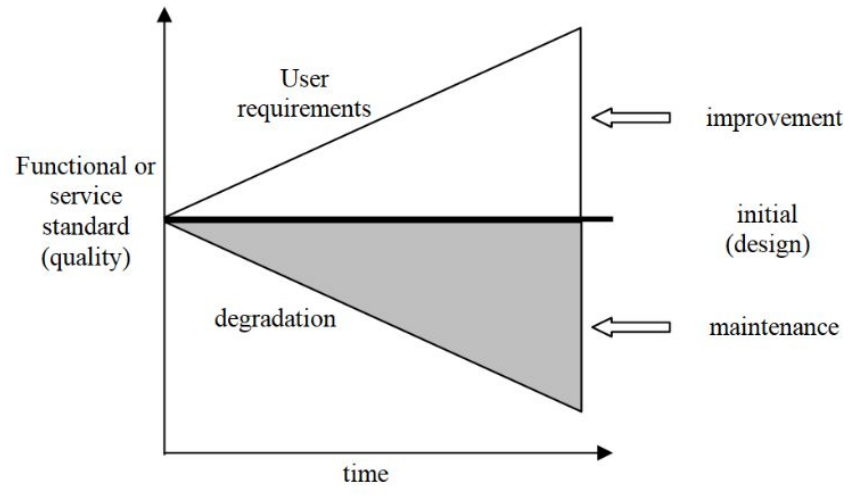

Figure 1. Time relationships with building functions (Stanford, 2010)

\subsection{Classification of State Buildings}

Government of Indonesia through the Minister of Settlements and Regional Infrastructure issued a regulation on Technical Guidelines for Building State Building (PPW Regulation No 332/KPTS/M/2002, 2002) dated 21 August 2002, this regulation is a guideline for government agencies in carrying out development. In this regulation, the classification of buildings is also regulated according to their function, while the calcification of the building is as follows : 


\subsubsection{Simple building.}

A simple building is a building whose characteristics are simple and have a low level of technological complexity, or a state building that has a prototype design. The guarantee period for the failure of the building is for 10 (ten) years. Which includes the classification of Simple Buildings, among others:

a. office buildings that already have prototype designs, or office buildings with a number of floors up to 2 floors with an area of up to $500 \mathrm{~m} 2$;

b. building type $\mathrm{C}$ official house (Area $70 \mathrm{~m}^{2}$ allotment for echelon III officials), type $\mathrm{D}$ (Area $50 \mathrm{~m}^{2}$ allotment for echelon IV officials), and type $\mathrm{E}$ (Area $36 \mathrm{~m}^{2}$ allotment for staff) which is not multilevel;

c. basic and/or advanced education buildings with a number of floors up to 2 floors.

\subsubsection{Not Simple Building}

The classification of not simple buildings is State buildings with characters are not simple and have complex and or not simple technology. The guarantee period for the failure of the building is for 10 (ten) years. Which includes the classification of Non-Simple Buildings, including:

a. office building with no prototype design, or an office building with an area of more than $500 \mathrm{~m}^{2}$ or a multi-story office building above two floors.

b. the building of official houses types A and B; or official houses C, D, and E which are multi-floor,

c. Hospital buildings, Class A, B, C, and D.

d. University/academy higher education building; or a basic/advanced education building on two floors.

\subsubsection{Special Buildings}

Classification of special buildings is a state building that has specific uses and requirements, which in planning and implementation requires special completion/technology. The minimum guarantee period for building failure is 10 (ten) years. Which includes the classification of Special Buildings, among others:

a. State palace and home of president \& vice president

b. State guesthouse

c. Nuclear installation building

d. Laboratory building

e. AirPort,

f. Railway station

g. Sports stadium

h. Jail

i. Warehouse of dangerous objects

j. Monumental building

k. Building for defense

l. Indonesian government's representative office building abroad.

\subsection{Maintenance and Care of Buildings Organization}

At the State University of Padang, the organization of building maintenance and care is also adjusted to the condition of the building, starting from the level of complexity, area, and 
function. Building maintenance and care at the State University of Padang is managed under the Household section and BMN section.

\subsubsection{Building Maintenance and Care Organization Based on PU Regulation Number 24/PRT/M/ 2008 in 2008}

The organization of building maintenance and Care depends on how complicated and sophisticated a building is, which includes building area, building dimensions, building systems used, technology applied, as well as other technical and non-technical aspects such as :

a. The physical size of buildings.

b. The number of buildings.

c. Distance between buildings.

d. Mode of transportation used by workers and supervisors.

e. Production or operational performance of each location.

f. Types of equipment and supplies.

g. Types and functions of buildings.

The organization formed is responsible for the smooth operation of building use, the implementation of operations, and maintenance per procedures that have been determined efficiently and effectively by the agency.

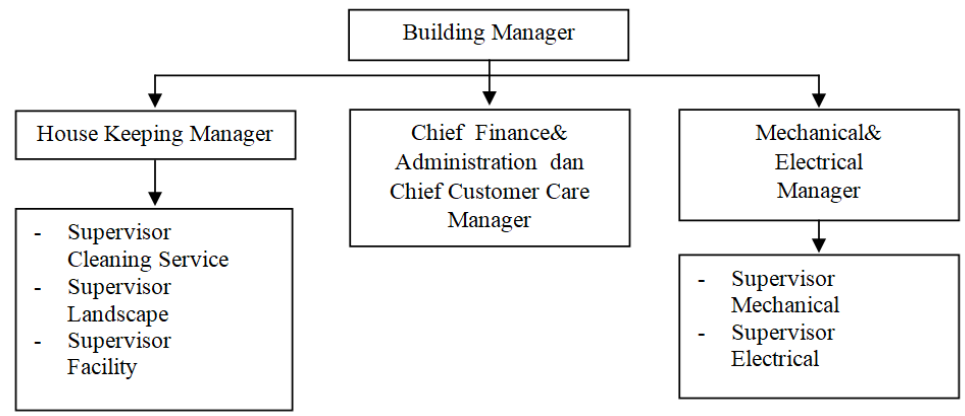

Figure 2. Organizational Structure of Maintenance and Care of Buildings (Supriyatna, 2016)

The following are the duties and responsibilities of each part of the building maintenance and care organization structure (PU Regulation No 24/PRT/M/2008, 2008):

a. Building Manager, Coordinating the work of all department heads.

b. Chief Engineering, Coordinate, direct, and supervise the activities of supervisors and implementers who are under their authority.

c. Chief House Keeping, Coordinate and give direction to supervisors.

d. Chief Customer Care, Coordinate, direct and supervise work activities under its coordination.

e. Chief Finance \& Administration, Coordinating, directing and supervising work activities that are under its coordination, in order to achieve work effectiveness and efficiency.

f. Engineering Supervisor, Conduct inspections to all parts of the building to see the condition of building equipment/equipment, installations, and utility buildings.

g. House Keeping Supervisor, Organize and supervise the implementation of cleanliness.

h. Fitter, Repairing the plumbing system; mechanic, Repair damaged machines; electrician, repairing damaged electrical installation. 


\subsubsection{Building Maintenance and Care Organization at UNP}

UNP also has a section that manages the maintenance and care of buildings; the form of the organization is also adjusted to the shape, extent, and function of the existing buildings. The building maintenance and care organization at the State University of Padang is as follows :

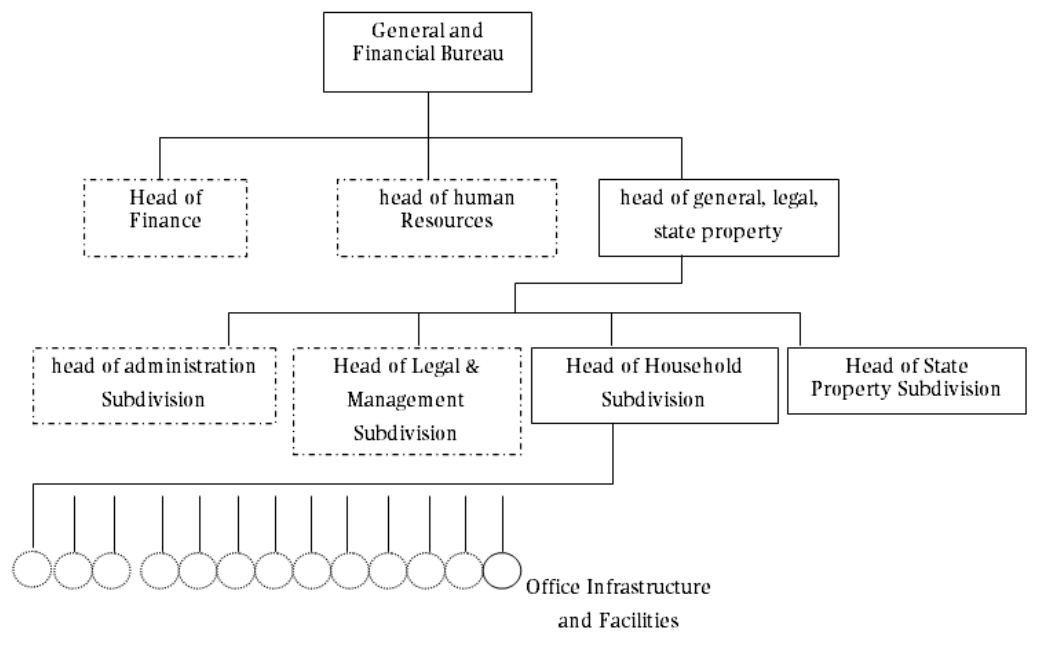

Figure 3. Maintenance and Care Flow of UNP

\subsection{Non-Governmental (Private) Building Maintenance and Care}

Like government buildings, buildings owned by private parties also do not escape maintenance and care needs. All buildings, both government-owned and private buildings, also experience a decline in quality and ability, the difference is that government buildings are built using state money while private buildings are built using private, group or company money. In general, buildings that are managed by the private sector tend to be cleaner, maintained, and efficient in obtaining, all parts are designed in an integrated manner to bring comfort to the wearer.

\subsection{Scope of Building Maintenance and Care}

The building maintenance and Care concept include: management activities which consist of physical management and others, where physical management consists of the maintenance and care of property management. It is necessary to remember that building maintenance is not intended to increase the capacity or capacity of the system or equipment above its maximum capacity, building maintenance is to prevent the building from all damage, as shown below (Mulyandari \& Saputra, 2011).

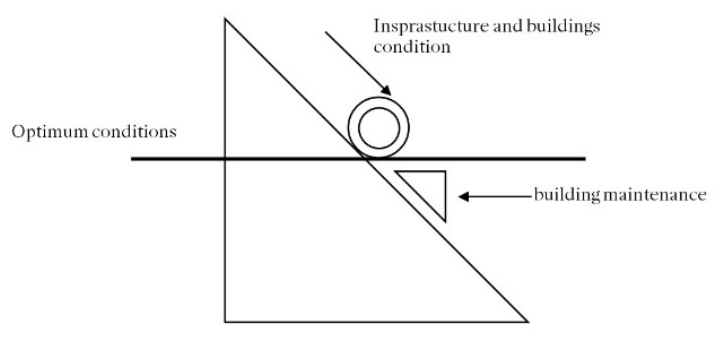

Figure 4. Importance of maintaining buildings against the condition of buildings and infrastructure (Mulyandari \& Saputra, 2011) 
Here are some categories in maintenance activities:

a. Regular Maintenance is a maintenance that is carried out continuously that has been planned

b. Periodic Maintenance is planned maintenance for components that are still used. This maintenance is carried out for components that have maintenance techniques and specialized expertise, such as cleaning and changing air conditioning channels, an inspection of fire safety systems, and others.

c. Long Term Maintenance, this maintenance is carried out to extend the economic life of a component by replacing elements of the component. Example: Replacement of elevator cables carried out $10-15$ years.

d. Maintenance of Building Structure, this maintenance is carried out to maintain a building from the building structure. Example: repairing corrosion that occurs on reinforced concrete surfaces.

e. Emergency Maintenance, this maintenance is done if there is damage to a component that was not previously estimated. This is done to anticipate the working system of the component. Example: Damage to electrical systems due to lightning strikes.

\section{RESEARCH METHOD}

\subsection{Methodology}

The method chosen to do this research is a descriptive method. Descriptive research is research carried out describing facts in a systematic, factual, and accurate way about facts. In descriptive research, the facts of the research results are presented as they are (Suryana, 2010).

\subsection{Data collection technique}

Data is collecting by direct observation in the field, distributing questionnaires to 70 respondents divided according to their functions (16 leaders, 12 managers, 30 executor, and 12 students), collecting maintenance documents and building drawings, literature from research results, journals, building maintenance, and care manuals. For interviews conducted with several university leaders after all field data and questionnaires were analyzed.

\subsection{Data analysis}

The questionnaire is filled in numerical form based on Thurstone scale with intervals of 1 10. After all the questions in the questionnaire are rated by the respondent, then all the values are summed up so that the values for each respondent's function (Leadership Level, Management Level, Implementation Level, and User Level) are obtained in the form of percentage values. Questionnaire data were analyzed using an excel program that was displayed in the form of bar charts. The values obtained from the questionnaires for each level of respondents were validated by the Triangulation method of data sources so that the values obtained in the form of number were included in the rating scale so that the assessment category of the application of PU Regulation Number 24/PRT/M/2008 was obtained. Assessments obtained from the results of data processing through questionnaires have not been used as conclusions in this study. An in-depth analysis of the compilers of the existing questionnaire needs to be carried out because in general respondents fill in the data, not in objective evaluation. After all, data is traced and separated based on existing problems, then confirm the data using limited interviews with several university leaders about the 
results obtained, especially regarding the shortcomings that exist, then the conclusion can be taken.

\section{RESULTS AND DISCUSSION}

\subsection{The following are some aspects that are directly observed in the research on Building Maintenance and Care at State University of Padang :}

a. Planning / Planning Aspects. In observing the Planning / Planning Aspects, conditions were found in the field where maintenance schedules were not well scheduled and only based on daily habits, while coordination in the organization had not been well established because there was no well-structured organization.

b. Organizing. In this aspect, there is no organizational structure that directly handles building maintenance and care, as well as an archiving system that is not well organized.

c. Actuating. In this section, most of which are carried out routinely are elements that are of beauty in use, such as gardens / outdoor courtyard, floor cleaning and appearance of the building. While the examination of all elements of the building is still very lacking, so that there are still many cracked walls, leaking concrete, leaking roofs, and ceilings, emergency maintenance of untreated pliers, corrosive in parts of the building, mossy.

d. Control. In this section no document is neatly arranged in the form of track records of buildings from various fields of the Field; Mechanical, electrical, sanitation, parks, buildings and others about buildings. This information is only found verbally to certain people who have been involved in building maintenance.

e. Budgeting, in this case, has been made by existing regulations.

f. Staffing. In this section, there is no precise measurement of the duties, responsibilities, and authority, most of the assigned personnel feel responsible for all activities that exist, so that it often seems saturated when on duty as well as the absence of structured and scheduled debriefing about the skills in the field, debriefing is only an example when working in the field.

\subsection{Maintenance and Care of UNP Building According to Various Respondents}

\subsubsection{Leadership Element.}

The assessment of leadership elements on the maintenance and care of buildings at UNP is between $65.09 \%$ to $77.28 \%$, and this shows that the assessment of UNP leaders on building maintenance and care at the UNP, falls into the good category. But after being studied more deeply than the elements that build up the percentage value, it is known that the organizational aspect is the main problem in the leadership level assessment, which is $60 \%$.

\subsubsection{Manager Element.}

The assessment of the management element of the maintenance and care of buildings at State University of Padang is between $52.54 \%$ - 81.05\%, this shows that the assessment at the management level of the State University of Padang towards building maintenance and care at the State University of Padang is categorized as Good until well (diverse). After a more in-depth study of the value of the questionnaire obtained, problems can be found, including Personnel/staffing, Implementation, Planning, Organizing and control in implementation.

\subsubsection{Implementing element.}

At the implementation level, it was found that the average value was between $46.05 \%$ $75.26 \%$, this indicated that the assessment at the Implementing level of building 
maintenance and care at UNP was categorized as Good to Good (diverse). When viewed from the distribution of its value, it can be said that there are gaps in the understanding of building maintenance and care. Similar to the level of leaders and managers, the results of the assessment at the Implementing / User level tend to be the same as the previous assessment, but the difference is, the value for each question tends to be lower. The problem categories if included in the aspects of building maintenance and care are included in the category of weak planning, weak employee placement, organizational problems, implementation, and control in a weak field.

\subsubsection{User Elements.}

In the user element, the level of assessment of the Building Maintenance and Care performance is almost the same as the implementation level, which is between $46.84 \%$ $76.05 \%$.

UNP has carried out maintenance and Care of existing buildings and entered into good categories (based on questionnaires). However, building maintenance and care that has been carried out is still not done correctly, this can be seen from the pattern of assessment results that tend to lead to sufficient value. This is strengthened by direct observation in the field of maintenance and care patterns and the results of interviews with several leaders. If we are guided by PU Regulation No. 24/PRT/M/2008 and based on the results of field observations, building maintenance and care management at UNP falls into the unfavorable category.

From the results of the research that has been done, it is found that the existing stakeholders still view the maintenance and care of the building as an activity to beautify the appearance of the building alone, this is strengthened from the assessment results through questionnaires distributed tend to be dominated by actual work that has less influence on the optimization of building use. In addition, the existing personnel has not been given guidance and training on building maintenance and care.

\section{REFERENCES}

Corder, A. (1996). Maintenance Management Technique (in bahasa : Teknik Manajemen Pemeliharaan). Jakarta: Erlangga.

Husen, A. (2009). Manajemen Proyek. Yogyakarta: ANDI OFFSET.

Iveta Pukiitea, M. s. (2017). Different Approaches to Building Management and Maintenance Meaning Explanation. Procedia Engineering (p. 906). Latvia: Elsevier Ltd.

Mulyandari, H., \& Saputra, R. A. (2011). Building Maintenance: Basic Skill Facility Management (in bahasa: Pemeliharaan Bagunan :Basic Skill Facility Management). Yogyakarta: Andi Offset.

PPW Regulation No 332/KPTS/M/2002, P. P. (2002, August 21). Technical Guidelines for Build Government Buildings (in bahasa: Pedoman Teknis Pembangunan Bangunan Gedung Negara). Technical Guidelines for Build Government Buildings (in bahasa: Pedoman Teknis Pembangunan Bangunan Gedung Negara) . Jakarta, Jakarta, Indonesia: Minister of Housing and Regional Infrastructure.

PU Regulation No 24/PRT/M/2008, D. P. (2008, Desember 30). Building Maintenance and Care Guidelines. Minister of Public Works Regulation . Jakarta, Jakarta, Kebayoran Baru: Direktorat Jenderal Cipta Karya.

Rilatupa, J. (2008). Estimated Decrease in Reliability of High Building Construction Components (in bahasa: Perkiraan Penurunan Kehandalan Komponen Konstruksi Bangunan Tinggi). Jurnal Sains dan Teknologi EMAS , 247.

Stanford, H. W. (2010). Effective Building Maintenance : Protection of Capital Assets. Lilburn: Fairmont Press, Inc. 
Suffian, A. (2013). Some Common Maintenance Problems and Building Defects: Our Experiences. Procedia Engineering (p. 101). Surakarta: Elsevier Ltd.

Supriyatna. (2016). Estimation of Building Maintenance Costs. Dalam Supriyatna, Estimation of Building Maintenance Costs (in bahasa: Estimasi Biaya Pemeliharaan Bangunan Gedung) (p. 199-205). Bandung: Unikom.

Suryana. (2010). Research methodology. Practical Models of Quantitative and Qualitative Research (in bahasa: Model Prakatis Penelitian Kuantitatif dan Kualitatif). Bandung, Jawa Barat, Indonesia: Universitas Pendidikan Indonesia.

UNP. (2018, January 16). History of UNP. Accessed at January 16, 2018, retrieved from http://www.unp.ac.id 